\title{
A case for two voices in Old Church Slavonic - reflexively marked OCS verbs*
}

\author{
Anna Malicka-Kleparska \\ John Paul II Catholic University of Lublin, Poland
}

\begin{abstract}
Old Church Slavonic data manifest significant similarities in the distribution and formal properties of anticausatives, reflexives, subject experiencer verbs, statives, and reciprocals, while their semantics may also be viewed as partly uniform. The structures representing the said classes of verbs are very frequent in the language, while passive structures, formed with analytic morpho-syntactic constructions, are relatively infrequent. Consequently, the expressions headed by anticausatives, reflexives, subject experiencer verbs, statives, and reciprocals (as well as dative impersonal structures) encroach on the area of semantics belonging in Modern Slavic to be the realm expressed in terms of passive morpho-syntax. The conclusion that can be drawn from this state of affairs is that Old Church Slavonic is characterized by the opposition of active and middle voices, while the passive voice is in its infancy.
\end{abstract}

Keywords: middle voice, passive, anticausative, subject experiencer verb, reflexive, Old Church Slavonic

\section{From PIE medio-passives to Old Church Slavonic reflexives}

The massive appearance of the reflexively marked forms in Old Church Slavonic (henceforth OCS) is tied in with the restructuring of the inflectional pattern, which underwent significant changes with respect to Proto-Indo-European (henceforth PIE). The Slavonic system is seen as developing the transitive accusative syntax, with the causative verbs being the model transitives, based on the stems most clearly marked with the vowel $-i-$. On the other pole of the transitivity scale, reflexively marked monoargumental formations have appeared, with a variety of uses which can be described as middle and which may have evolved from the PIE auto-benefactives (see Gorković-Major 2009), medio-passives or are an exclusively Slavic modification. The prevailing view is that the inflectionally marked middle voice of PIE got lost and, consequently, the gap had to be replaced with an inflectional pattern which would attend

\footnotetext{
* I would like to express my gratitude to the anonymous reviewers of my paper, who have not only pointed out some drawbacks of an early version of my work, but also have given me a new impulse and direction for my future studies on Old Church Slavonic.
} 
to the cases where the information of the clause pivots around a single argument undergoing some change (Savčenko 1974, Madariaga 2010). As Old Church Slavonic did not drift into the area of ergative languages, where the distinction between transitive and intransitive clauses could be case marked, it had to develop a system to perform a similar distinguishing function. The system might continue the PIE auto-benefactive marking (see Gorković-Major 2009, cf. however, Madariaga 2010), and it has adopted the form of verbs which, although endowed with the active voice inflection, yet possess a common marker of intransivity: a clitic form has developed, which reflects the PIE reflexive pronoun ${ }^{*} s(u) e$ - (see Cennamo 1993: 278), and which we will render as $s e .{ }^{1}$

The use of the reflexive forms in Old Church Slavonic has been discussed in varying detail (see e.g. Brajerski 1966, Lunt 2001, Krause and Slocum 2013, Kulikov 2011, 2013, Madariaga 2010), but we feel that it still lacks an all-encompassing account linked with theoretical proposals bearing on the event structure. This paper is designed to fill this gap.

The reflexive element se appears in the monoargumental clauses, where the argument undergoes some change or directs an activity upon itself (see $1 \mathrm{a}$ ), and not in the clauses with a single argument and just any intransitive (unergative) verb (see $1 \mathrm{~b}$ ).

(1) Intransitives:

a. 1061600 postite sę 'Fast!' 2.PL.IMP

b. 1052800 vǐž̌ritǔ 'look' 3.SG.PRES

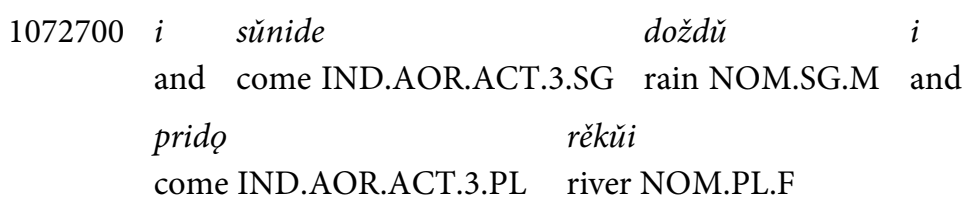

In other words, OCS has also intransitive verbs which are not reflexively marked.

The reflexives in Old Church Slavonic seem to have taken up the function of actor directed middle voice structures of PIE (the PIE indirect reflexive meaning, see Madariaga 2010) and have extended it to all mono-argumantal propositions directed at the argument. PIE also marked states with medio-passive voice inflection (stative verbs, which were characterized by the morpheme $-y a-$, see Jasanoff 1978) and OCS seems to have translated this pattern into the reflexive structure as well. ${ }^{2}$

Thus, from the viewpoint of semantics, OCS reflexively marked structures have assumed the role of the medio-passive voice in PIE. The concept of voice, as seen in the line of tradition that resulted in the development of Distributed Morphology (Alexiadou and Doron 2012, Pylkkänen 2008, Marantz 1984, Kratzer 1996,), addresses the issue of participants in a

1 In this paper we will use transliterations of the original Old Church Slavonic forms, which are obscure enough as they are. The system of transliteration has been adopted after Lunt (2001). The quotations are given line numbers from the Corpus Cyrillo-Methodianum Helsingiense. The first digit stands for a particular Gospel: Matthew (1), Mark (2), Luke (3), John (4). The next two digits give the number of a particular verse, while the remaining numbers mark sections of this verse (wherever applicable).

2 Madariaga (2010) claim that statives were not marked with sę in OCS. We have been able to find such cases, albeit not very numerous (see 5 below), and consequently we uphold the position that statives are middle verbs after all. 
morpho-syntactic structure. The active voice, prototypically, targets two participants, i.e. the performer of an act and the undergoer of this act, and hence in the structure-oriented descriptions of the morpho-syntax the conception of this voice is connected with the introduction of an appropriate projection, which in its specifier hosts the external argument (Marantz 1984, Kratzer 1996, Pylkkänen 2008). The passive voice concentrates on the undergoer in an event. Usually, some overt relationship with the active voice is preserved in the form of passive predication and some mention of the actant participant (Agent) is also possible. The middle voice may have no formal relationship to active or passive voices and it targets the only argument of the predication, which constitutes the sole center of an event. Most typically the argument undergoes some change of state. Actually, a lot of similarities between the passive voice and the middle voice can be noticed, both formally and semantically (the undergoer is focused in an event - see e.g. 25 below), with the difference that in the middle voice the interference of an outsider Agent into the event described is much more obscure, or indeed absent altogether, unlike in the passive voice (see Madariaga 2010). Middle voice structures make no place for the external participant: It can be present, but as a nonsubcategorized argument, and not as a logical argument of the predicate. Thus such a participant is couched in the context or introduced by a modifying phrase, and the formation of the middle voice does not depend on it in any way.

The term middle voice goes back to studies of Greek, in which the middle voice constructions strictly concerned categories where the participants in the proposition directed events upon themselves (see e.g. Madariaga 2010, Alexiadou and Doron 2012). The same function is projected onto the Old Church Slavonic reflexively marked verbs, as observed by e.g. Vaillant $(1965,2002)$ : according to him the verbs render the events described from the point of view of the subject affectedness. Lunt (2001: 158), on the other hand, states that the se structures in Old Church Slavonic express passive voice (competing with periphrastic constructions with the verb byti 'be'). Another approach depicts se verbs as designating intransitives in general (Krause and Slocum 2013). ${ }^{3}$

In this paper we aim at finding the morpho-syntactic structures of Slavic reflexive formations, which in the construction-based approach are to directly reflect their semantic properties. We shall test and prove wrong the assumptions that they simply reflect the intransitive valency. Instead, we will claim that they constitute a morpho-syntactic middle voice category, characterized by specific semantics. In this text we will support Vaillant's (1965) intuition about the semantics and formal side of these verbs being two sides of one coin.

More recent descriptions of voice related phenomena within the Nanosyntax would not necessary imply any of the above positions, but present a strictly structural definition of the middle voice, where the active voice would differ from the middle voice in having the active voice projection introducing the external argument, while the semantics of a proposition

3 Cennamo (1995:48-49), when she talks of split intransivity, stresses the fact that in Romance languages a distinction was made between unergative and unaccusative verbs marked by the reflexive marking se/sibi. It seems that a similar distinction is made in Old Church Slavonic, i.e. a distinction between intransitives of unaccusative type marked with $s e$ and unergatives, which are not marked at all. 
could be a proper parallel of the Greek middle voice. For instance anticausatives, semantically decidedly middle, can be ascribed structures characteristic of the transitive verbs, which, deprived of the internal surface argument end up as unergatives (see e.g. Medová 2011).

The situation which we come across in OCS is better reflected by the understanding of the middle voice which is proposed in Alexiadou and Doron (2012), who link the term: middle voice with the appearance of characteristic morphology and a cluster of semantic functions. These functions are the reflexive function, reciprocal function, anticausative function, dispositional middle, medio-passive and passive. However, on the top of such uses, OCS reflexively marked verbs also show the function which can be termed as auto-benefactive (for psychological experiencer verbs) (and which might continue a PIE function). All these functions correlate with the reflexive marking and as reflexive forms are strikingly frequent in OCS this may support the conception of OCS as a two voice system - with the active voice and reflexively marked middle, with largely encroaches upon the function of the passive voice. It has to be stressed that analytically formed passive structures are exceedingly rare in OCS.

In structural terms we will represent the non-active (middle) voice as a projection headed by the reflexive clitic and dominating a projection with the internal argument - which ultimately ends up realized as the surface subject.

The Gospel of St. Matthew ${ }^{4}$ from the Codex Marianus in the Corpus CyrilloMethodianum Helsingiense has been selected as the data base.

\section{The data}

The reflexive-like formations in OCS are marked by the presence of the clitic element se, which takes the form of the reflexive third person singular pronoun - identical for all the three genders in OCS (see Lunt 2001). ${ }^{5}$

As Old Church Slavonic data is not well known, we will present the relevant groups of verbs in some detail.

\subsection{Anticausatives}

The most numerous group of OCS verbs accompanied by the clitic $s e$ are anticausative verbs. They are almost without exception prefixed, ${ }^{6}$ which will be treated as crucial in our further analysis. They appear with nominative subjects, as the example in (2) below shows:

$\begin{array}{lllll}\text { (2) Vǐš̌kŭ } & \text { sadǔ } & \ldots & \text { iskorenitǔ } & \text { se } \\ & \text { all } & \text { plant } & \text { uproot } & \text { refl } \\ & \text { POS.NOM.SG.M.STRONG } & \text { NOM.SG.M } & \text { IND.PRES.ACT.3.SG } & \text { ACC. SG., M./F./N. }\end{array}$

'Each plant will get uprooted.' (1151300)

\footnotetext{
${ }_{4}^{4}$ Occasionally, when relevant data was not available therein, other Gospels from the same source have been quoted.

5 The pronoun has a longer variant sebe, which is, however, rarely used, and only in focused contexts (see Lunt 2001).

6 Prefixes will be given in bold characters in our paper, wherever relevant.
} 
The anticausatives we have found in the text are very numerous, so it seems that this way of forming single argument predications in OCS was very productive. We find anticausatives and causatives based on the same roots, ${ }^{7}$ so probably the reflexivization technique was a productive way of bringing about the opposition in voice.

(3) The anticausative verbs:

da sŭboqdetǔ sę 'in order to come about' 1081700 come about 3.SG.PRES. REFL

iskorenitǔ sę 'uproot' 1151310 uproot 3.SG.PRES

ištisti sę 'heal' 1080300 heal 2.SG. IMP REFL

iskazišę sę sami 'make' 1191220 make 3.PL.AOR

nasǔitiše sę 'fill' 1153700 fill 3.PL. AOR

naučite sę 'teach yourself 1091300,1112900 teach 2.PL.IMP

opravídi sę 'get excused, right' 1111920 excuse 3.SG.IMP

otrvěste sę 'opened' 1093000 open 3.DU. AOR

otǔimetǔ sę 'depart' 1091510 depart 3.SG.PRES

otǔpuštajotǔ sę 'get annulled' 1090220 annul 3.PL.PRES

podobite sę 'become similar' 1060800 become similar 2.PL.IMP

pokaašę sę 'got converted' 1112010 convert 3.Dual.AOR

pokaži sę 'show yourself 1080400 show 2. SG.IMP

pokryvati sę 'cover' 1082400 cover INF.REFL

postętǔ sę 'they will fast' 1091520 fast.3.PL.PRES

prěkratili sę 'shorten' ř 1242200 shorten COND.PART

prěobrazi sę 'change' 1170200 change 3.SG AOR

približi sę 'will come, become near' 1100700 come 3.SG.IMP

prosędotǔ sę 'they will break' 1091710 break 3.PL.PRES

prosvitě sę 'lighten' 1170200 lighten 3.SG.AOR

razdělǔ sę na sę 'breach' 1122500 breach PART

razidotǔ sę 'scatter' 1263200 scatter 3.PL.PRES

razoritǔ sę 'break' 1240220 break 3.SG PRES

sǔblaznišę sę ‘shock' 1151210 shock3.PL.AOR

sǔbljudetǔ sę 'preserve'1091720 preserve3.PL.PRES

sǔbodetǔ sę 'fulfill itself 1121700 fulfill 3.SG.PRES

sǔkrušitǔ sę 'break' 1214400 break 3.SG.PPES

sǔměritǔ sę 'lower' 1231200 lower 3.SG.PRES

sŭmiri sę 'get to be on peaceful terms' 1052400 make peace 2.SG. IMP REFL

upodobi sę 'be similar' 1220200 be similar 2.SG.IMP.

uvěštaje sę 'make peace' 1052500 make peace 2.PL.IMP REFL

v̌znesǔii sę 'rise’ 1112300 rise PART. PST. ACT. NOM. SG.

vizvěsi sę 'hang' 1270500 PART

vizdrěmasę sę 'nap' 1250500 nap 3.PL.AOR

vŭpadjetǔ sę 'fall' 1121110 fall 3.SG.PRES

vŭzalkahǔ $[\ldots]$ sę 'get hungry' 1254200 get hungry1.SG. IMP

vǔždędahǔ sę 'get thirsty' 1253500 get thirsty 1 .SG. IMP

Very few anticausatives are not prefixed, like for instance the ones in (4) below:

7 Compare, for instance, the transitive and the reflexive verbs in: 1080210 možeši mę ištisti 'You may cure me' vs. 1080310 ištisti sę 'Be cured'. 
(4) Unprefixed anticausatives

avili sę 'appear' 1061620 appear CONDIT-OPTATIVE

rodišę sę 'get born' 1191200 get born 3.PL.AOR

ne pade sę 'it did not fall' 1072520 not fall 3.SG.AOR

\subsection{Statives}

The next group of reflexively marked verbs are statives. They are not very frequent in our data, still they appear, (cf, however, Madariaga 2010). Statives are rather unprefixed and they do not refer to any change of state:

(5) Statives

avlěate sę ‘seem' 1232800 2.PL.PRES

črǔmǔnuetǔ sę 'look red' 1160210 redden 3.SG PRES

ostavlěatǔ sę 'remain' 1244100 3.SG.PRES

hranite [...] sę 'be protected' 1161110 protect 2.PL IMP

plakati sę 'cry' 1091500 cry INF

We will claim in this paper that statives possess the structure common with a subclass of Subject Experiencer verbs, and this will make these verbs more prominent and more numerous than the sample above seems to suggest.

\subsection{Subject Experiencer verbs}

Experiencer verbs are traditionally believed to be a specific group of predicates (Belletti and Rizzi 1988, Rothmayer 2009, Landau 2010, Rozwadowska to appear), but their structure in OCS shows that they should rather be analyzed together with anticausative and stative verbs. They show the properties of both groups of verbs, and, like them, are equipped with the reflexive morpheme sę. Some of them (in 6a) resemble statives in that they do not specify a change of state and are not prefixed, some (in 6b) resemble anticausatives because they specify the change of state, and are prefixed in ways analogical to anticausatives (see 3 above).

(6) Subject Experiencer verbs

a. bluděte sę 'beware' 1160600 beware 2.PL.IMP

boite [...] se 'be afraid' 1102810 be afraid 2.PL.IMP

čjudiše sę ‘be surprised' 1082700 be surprised 3.PL.IMPRF

divišę sę 'be surprised' 1093300 be surprised 3.PL.IMPR

sę pečete, pǐčete sę 'care' 1062800,1063100 care 2.PL.PRES

raduita se 'be glad' 1280900 be glad 2.PL.IMP

ne protiviti sę 'not oppose' 1053900 not oppose INFT

truždajotǔ sę 'toil' 1062810 toil 3.PL.PRES

b. ne uboite sę 'do not be afraid' 1102600,1102800 be afraid 2.PL.IMP

pogněvavǔ sę 'get angry' 1183400 PART

razgnèva sę ' get angry' 1220700 3.SG.PRES

sǔblaznitǔ sę 'doubt' 1110600 doubt 3.SG.PRES 


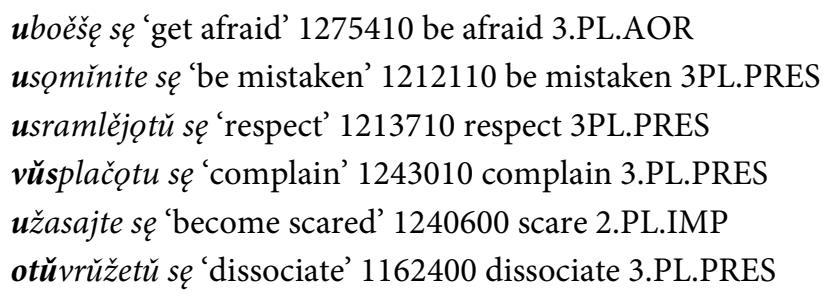

Subject Experiencer verbs are such predicates that specify emotions experienced by their subjects. Thus they fit the definition of middle voice predicates adopted in this text. They are marked in the uniform way with $s e$, just like other middle voice predicates.

\subsection{Reflexives}

Reflexive verbs in OCS do not seem to differ significantly from anticausatives, the only distinction being that they describe not the change of state, but the action directed at the argument, and the argument is animate in character. This is frequently treated as a mark of the unergative structure of verbs (see Medová 2012), but we propose that reflexives are basically like unaccusatives ${ }^{8}$, the only difference being that their roots require the animacy and agentivity of their internal arguments. In this way the reflexive reading is imposed on the predicates, otherwise anticausative in their structure.

(7) Reflexives

oblěče sę 'dress' 1062900 dress 3.SG.AOR

obratętǔ sę 'get converted' 1131530 conver 3PL.PRES

odeždemǔ sę 'dress' 106310 dress 1.PL.PRES

prilěpitǔ sę ‘join'1190510 join 3.SG.PRES

sę pomaži 'smear' 1061700 smear 2.SG.IMP

vǔzvratitǔ sę, vzrašto sę 'come back' 1101310 return 3.SG.PRES 1.SG.PRES

dvigni sę 'get up' 1212120 get up 2.SG.IMP

potręse sę 'move' 1211000 move 3.SG.AOR

prědastǔ sę 'hand in' 1262410 give 3.SG.PRES

prikosnotǔ sę 'touch' 1143600 touch PL.PRES

\subsection{Reciprocals}

Two reciprocal forms are found in our data, ${ }^{9}$ which we consider to be structurally identical with the reflexive, the difference resulting from the semantics of the stem, enforcing reciprocality on the interpretation of the obligatorily collective argument.

\footnotetext{
8 Junghanns, Fermann, Lenertová (2011) present a view on anticausatives, which is the opposite. They are viewed as basically reflexive transitive structures, where the external argument is not specified for Agentivity. Here we adopt the opposite optics, i.e. reflexives are seen as a type of anticausatives, where the argument which is internal is nevertheless animate and Agentive.

9 Possibly just one, as the verb ženiti sę 'get married' is used in our data for the male partner of a couple and then it should be classified as an anticausative verb.
} 
(8) Reciprocals

sǔbǔrašę sę 'gather' 1223410 gather 3.PL.AOR

ženiti sę 'get married' 1191010 marry INF

\section{The model}

The theoretical model we have adopted for the analysis of this body of data is the root-based construction model as proposed by e.g. Pylkkänen (2008), Alexiadou and Anagnostopoulou (2004), Embick (2004, 2009), Alexiadou (2010), Alexiadou and Doron (2012), Lomashvili (2011).

In this model, morphologically complex structures result from the operation of merge, identical with the one active in the syntactic component (see Chomsky 1995). Consequently, no separation of the two spheres of language is recognized: Morphological structures are integrated with syntactic ones into a uniform system with the same principles, properties and procedures. Argumentation from the side of clause structure is admissible in building the morphologically complex verb itself.

The basic unit in a structure is the morpheme (and not a word). Roots have a specific position in this system because they are basic, indispensable elements for constructing a morpho-syntactic complex. They are category-less, which means that they acquire the category thanks to the structure they are situated in. Roots, however, are associated with some encyclopedic meaning and are marked for various kinds of idiosyncratic information, e.g. what kind of argument they co-occur with. Some roots appear obligatorily with animate arguments, e.g. play, some with more highly specified ones, e.g. grow, melt.

As all morpho-syntactic forms are made from scratch, no morphological rules are believed to turn one brand of verb into another brand. All existing similarities have to be expressed with the use of similar morpho-syntactic structures (and with morphemes introduced in them), as well as with the appearance of the same roots.

\section{Analysis}

As the formations with se are uniformely mono-argumentals, with the semantics targeting (predominately $)^{10}$ the state or the change of state of the single argument present, we assume that the clitic se is a marker of the middle voice, and more precisely the middle voice head. The morpho-syntax of the verbs marked with the clitic is situated below the middle voice projection. The simplest structures are representative for statives, in which the only argument of the clause is originally the complement of the Stative Head - the root (see 9 below). The root specifies the state of the internal argument, while the $\mathrm{V}$ projection contributes the verbal category (see e.g. Embick 2009), whose head in the case of OCS statives may be the morphological zero or an overt suffix. Consequently, statives possess only the properties resulting from the information supplied by the root and the verbal category. The structure

\footnotetext{
10 Exceptions will be discussed in section 5 .
} 
illustrating a stative verb in OCS is given for: črǔmǔnuetǔ PRES.3.SG sę REFL nbo NOM.SG 'The sky looks red'

(9) Structure for statives:

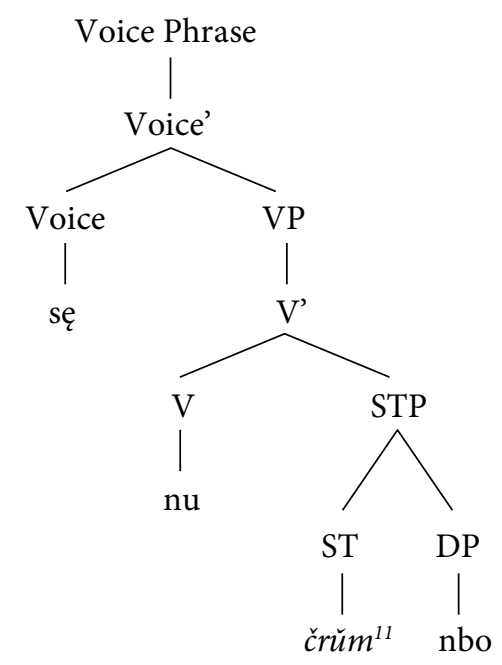

The verbalizing morphology is situated under $\mathrm{V}$, which, depending on a particular verb (group of verbs) may be overt, or may be represented by the morphological zero, which is then a place-holder introducing the category marking. In the example we have chosen, it is spelled out by -nu-. The stative verbs in OCS are basically verbalized roots equipped with verbal inflection, the fact reflected in their maximally simple morpho-syntactic structure.

The next group of middle verbs are anticausatives, which, in contra-distinction to statives, are prefixed. We believe that the prefix constitutes the head of the process forming projection (see e.g. Ramchand 2008), as these verbs are change of state predicates, so apart from the state, the inchoative semantics must be incorporated. Consequently, the representation is richer by one projection, whose presence signals that there is a process in operation. ${ }^{12}$ Thus anticausatives and statives based on the same roots are going to be differentiated by the presence of an additional projection. The heads of this projection in OCS are prefixes. In the case illustrated in (10) the prefix takes the form of is- , while the verbalizing head is realized as the suffix -i-. The structure is given for: saď̌ [...] iskorenitǔ se (see 2) 'The plant got uprooted': ${ }^{13}$

${ }^{11}$ The root has been reconstructed from the forms of related verbs available in Slovnik jazyka staroslověnského (Lexicon linguae palaeosloveni).

${ }^{12}$ Notice that the view upon morpho-syntactic structure is here distinct form that recognized in the Nanosyntax in that the higher layers of structure do not have to automatically imply all the lower levels (see e.g. Pantcheva 2009). Stative verbs will not subsume the processual projection in their structures at all, in spite of the fact that they contain the middle voice projection and the characteristic morphological marking.

13 The translations with 'get' do not suggest that there is some external force implied in the predication. English is poorer in anticausatives than OCS and hence analytic structures have to be used in translations from time to time. 
(10) Anticausatives:

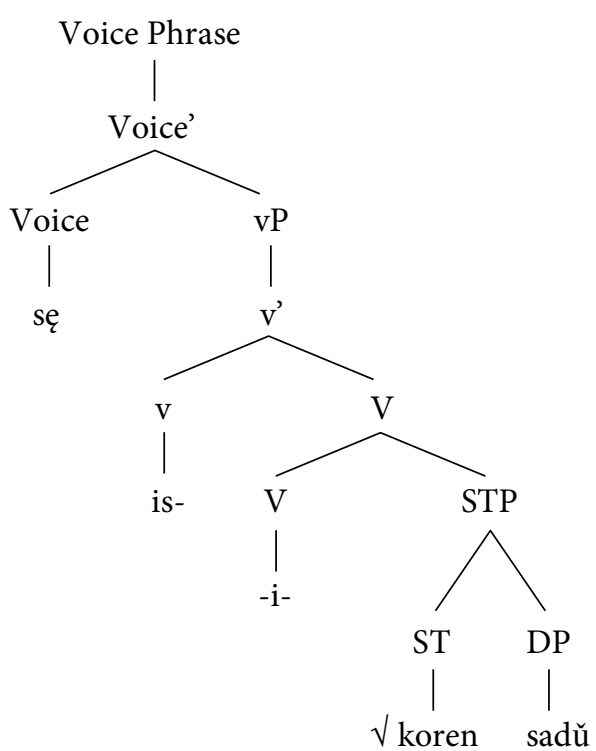

Likewise, Subject Experiencer verbs will also appear in two groups. The ones which are unprefixed and specify no processual semantics will have the structure identical to statives, see (9) above. They will differ from other statives in the specification of their roots, which require [+mental] arguments (see e.g. Everaert, Marelj and Siloni 2012), it is the arguments which are endowed with the cognitive ability of thinking. The example illustrated in the structure (11) below is: 3104100 denı̌ NOM.SG [...] pečetǔ IMP.2.SG sę 'The day worries (about itself)':

(11) Subject Experiencer verbs (stative):

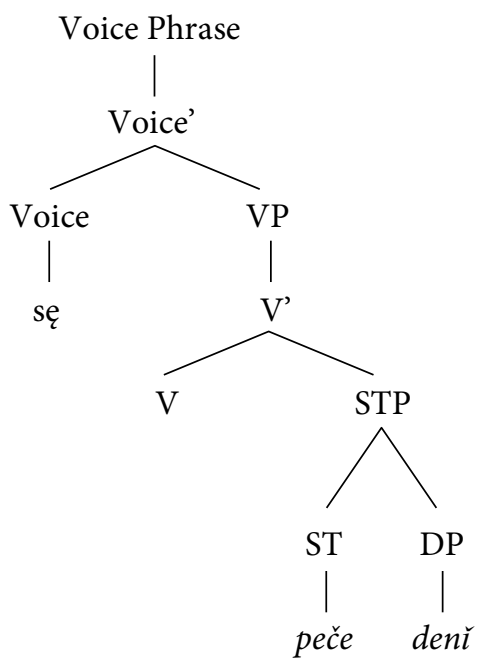

On the other hand, the Subject Experiencer verbs which are prefixed normally bring about the change of state, and, consequently, they will have the processual projection in their representation: 1220700 csr NOM.SG [...] razgnèva AOR.3.SG sę REFL 'The Tsar (ruler) got angry'. 
(12)

Subject Experiencer verbs (processual):

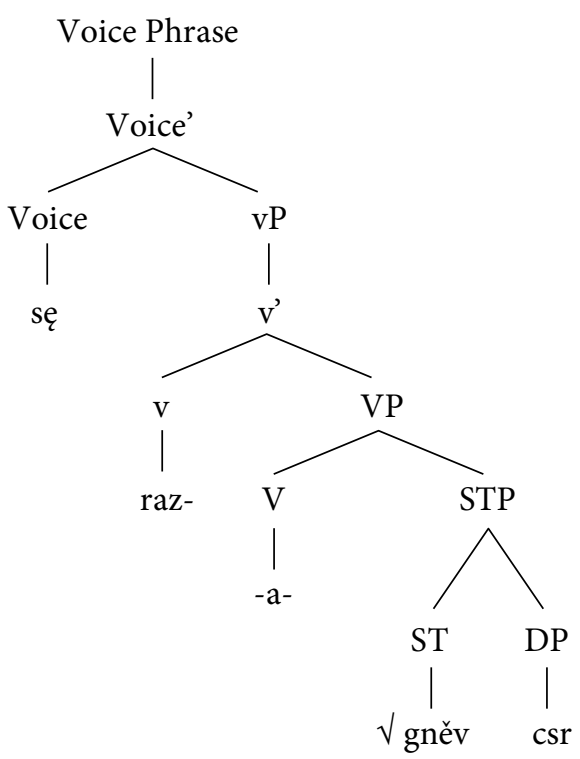

In this particular form the verbalizing suffix is the vowel $-a$-, and the head introducing the processual projection is raz-.

We believe that reflexives and reciprocals are no different from anticausatives in terms of structure. The difference lies in the specification of their roots, which require animacy of their arguments, and the semantics is automatically adjusted. This representation of reflexive verbal uses is unorthodox, but the clause structure in which reflexives are inserted in OCS gives no reason to believe that reflexives are any different than other middle voice uses of verbs. This solution is a mirror image of Junghanns, Fermann and Lehnertová (2011) proposal for the derivation of anticausatives. Their anticausatives are like reflexives, but the fact that causes of the change of state have not been specified makes the anticausative reading available. We argue that reflexives are basically unaccusatives, with eventive roots taking animate arguments. We adopt this solution because of the middle semantics and regular marking of all such verbs as middles.

As the illustrations above shows, verbal derivational morphology in OCS consists predominantly in middle morphology. Another group of structures with se, which also have the middle semantics are impersonal structures with the reflexive marker. They are constructed with the $3^{\text {rd }}$ person singular verb, and the argument of the verb being realized in the Dative case. Again, these structures serve the function of creating middle voice structures, concentrated on a single argument:

(13) Sę impersonals

\begin{tabular}{|c|c|c|c|c|}
\hline $\begin{array}{r}2131120 \text { eže } \\
\text { what }\end{array}$ & $\begin{array}{c}{[\ldots] \text { dastǔ }} \\
\text { give }\end{array}$ & $\begin{array}{l}\text { sę } \\
\text { refl }\end{array}$ & $\begin{array}{l}\text { vamǔ } \\
\text { you }\end{array}$ & $\begin{array}{l}{[\ldots] \text { glagolete }} \\
\text { say }\end{array}$ \\
\hline REL.PRON.NOM.SG. & IND. PRES.ACT.3.SG. & REFL & DAT_PRON.2.PL & PRES., ACT., 2ND P., PL. \\
\hline
\end{tabular}

The impersonals have similar semantics, as they specify what happens to the internal argument. We believe that they also possess structures topped up with the middle voice 
projection and an additional applicative argument, but we are not going to analyze them within the limits of this paper as they require a separate study.

This representation of the forms marked with $s e$ in OCS reflects the uniform function of the introduction of the structures with the clitic, allowing us at the same time to depict the necessary differentiations among the forms. The uniform middle voice head defines the family of functionally identical constructions. The head prevents the external argument from being introduced on the top of the event involving the internal argument and it delimits the event's semantics as focused on the internal argument. The differences between particular word groups result from the number of projections that they encompass and properties of the roots (e.g. Experiencer verbs have roots requiring a sentient argument).

If the same root builds two different constructions, then the difference is limited to the distinction made thanks to particular projections. The case in point is e.g. the root avi, which appears in both stative and anticausative constructions, in one having the stative (14a), in the other the anticausative (14b) use. The verbs differ in their semantic content because of the processual projection contained in anticausatives:

Statives/anticausatives

a. avlěate sę 'seem' 1232800 2.PL.PRES

b. avili sę 'appear' 1061620 appear CONDIT-OPTATIVE

The system of the middle voice semantics seems to be beautifully simple. Nevertheless, there are cases which do not fit this picture, albeit infrequent in the OCS system.

\section{Exceptional forms}

Apart from the forms with the middle voice semantics, OCS possesses the forms which do not fit the pattern. These are reflexiva tantum with unergative semantics.

(15) Reflexiva tantum

klaněše sę 'bow' 1080200 bow 3.SG AOR

moliši sę 'prey' 1060500 prey 2.SG. PRES INF

rotiti sę 'vow' 1267400 vow INF

As all these forms have similar meanings we assume that they may be analogical formations marking the subservient position with respect to the deity.

\section{An alternative analysis of Subject Experiencer verbs in OCS - Madariaga (2010)}

An interesting analysis of a subclass of OCS reflexive verbs has been presented by Madariaga (2010). The gist of her theory concerning a subclass of mental 'separation' verbs (bojati sę be afraid') is that the clitic element $s e$ is in fact a pronominal element in the Accusative case. Consequently, this pronoun prevents any other argument to be marked with the structural Accusative within the event projection, while the other argument lands up in the specifier of the voice phrase, as the derived subject. The verbs she writes about appear in OCS with the 
Genitive complement expressing the older Ablative function. They belong to a larger group of mental activity verbs, in which they are specific in showing the Genitive complementation. ${ }^{14}$

Madariaga's analysis is at odds with the views on the structure of OCS reflexively marked predicates which we have presented here. We do not view se as a pronoun, nor as an argument, as our whole conception of the middle voice in OCS depends on the monoargumental nature of the relevant predicates.

However, we will show that Madariaga's (2010) arguments about the structure of mental 'separation' verbs may not be completely convincing.

First of all in the system of verbs that are reflexives, there are some verbs which are undoubtedly mono-argumental, i.e. statives. Madariaga (2010) gainsays their existence, however the examples in (5) show that such verbs do occur. So at least for one subclass of 'reflexive' verbs it would not make sense to assume that the element $s e ̨$ is a pronominal and , by extrapolation, it may not be pronominal in other contexts.

The Genitive case in Madariaga's system originates in the Ablative of PIE. However, some semantically similar predicates, resembling 'separation' verbs like bojati sę be afraid', do not show the complementation with the Genitive phrase:

(16) Separation verbs with non-Genitive complementation

picěte sę dšejo vašejo (INSTR) 1062500 'care about your soul'

protiviti sę zǔlu (DAT) 1053900 'object to evil'

divi sę emu (DAT) 1081000 'He was surprised at him'

We think that what has been disregarded is the Genitive of negation which may account for the Genitive case in Madariaga's examples (see however Madariaga 2009, where the Genitive of negation is considered in relation to Old Russian data). The Genitive case in Slavic languages realizes the arguments within the scope of negation, overt or otherwise. For instance in Polish and Slovene we have such expressions as:

(17) Genitive of negation in Polish and Slovene

Zabrakło chleba.bread.GEN (Pol) / Zmanjkalo kruha.bread.GEN (Slovene) 'There is no more bread.'

Mama nie dała chleba.bread.GEN (Pol) / Mama ni dal kruha.bread.GEN (Slovene) 'Mum did not give bread.'

Both in the overtly negatively marked clause, as well as in the clause which has not been marked in this way, the verbal complement is Genitive. The condition for the verb to appear with such a complement is its strongly negative semantics.

The reason why Madariaga's verb bojati se be afraid' is accompanied by the Genitive seems to be the very same Genitive of negation, and not the fact that the verb is situated in the morpho-syntactic structure with the assignment of the Accusative case blocked by a pronominal argument.

\footnotetext{
${ }^{14}$ Not all mental activity verbs require the Genitive complementation: E.g. moliti se in the mental activity verb group does not take the Genetive case, but the Dative: pomoli se otcu tvoemu.DAT 1060610 'pray to your father'.
} 
The mental activities that do not carry negative connotations do not show the Genitive complementation (see 9 above).

Then properties of $s e$ itself do not seem to support its pronominal status. OCS is a highly inflectional language, in which pronouns are inflected according to case, person, number and one of the three genders. Why should a pronoun exist in this system which has lost all of these properties, possessing just one syncretic form. Such a suggestion is highly suspicious. Also a long term effect of such 'weakening ' of a pronoun could be its disappearance. If we trace the history of the reflexively marked verbs e.g. in Polish we notice that even if the reflexive element went out of use, the verbs' complementation stayed unchanged (non-Accusative). In the history of these verbs, through Old Polish to Present-day Polish, many reflexively marked forms have been ousted by synthetic anticausatives, without any reflexive marking: (OCS) prosvitěti sę 'lighten' - Polish świtać 'lighten', (OCS) vǔpadati sę 'fall' - (Polish) opadać 'fall', (OCS) postiti sę 'fast' - (Polish) pościć 'fast'. In none of these cases did the Accusative argument appear with the verb 'freed' from the pronominal argument. As Madariaga links the formal (uninflected) properties of the alleged pronoun and its poor feature content, which, taken together, influence the syntactic structure in which the 'weak' pronoun functions, then the pronoun's total disappearance should free the place in the structure so far occupied with the pronominal element. Consequently the Accusative arguments should appear. As the example in (18) below shows, it is not the case.

(18) Nadzieja (NOM) świta. 'Hope dawns' vs. ${ }^{*}$ Nadzieje (ACC) świta/ ${ }^{\star} C o s ́$ świta nadzieję ‘ Something dawns hope'

Another problem is connected with the appearance of sebe, the alleged full ACC form of $s e$ (see Lunt 2001:103), which is supposed to be used in OCS as a form of $s e$ in the focused positions. If our predicates were complexes of a pronoun and the verb, occasionally the full form of the pronoun should appear in the structures with the reflexive verbs. It does not happen though in the case of the verbs with the middle semantics (19a). Moreover, if the verbs related in meaning and based on the same roots, but possessing no middle semantics are used, then the full pronominal form is attested (19b):

(19) Se/sebe structures based on the same root with middle/causative semantics

a. naricatisę otǔ člvkǔ rav̌rvi call.INFIN from man GEN.PL rabbi INSTR.PL to be called from men 'be called rabbis by men' 1230700 vs.

$\begin{array}{lllll}\text { b. otǔca } & \text { ne naricaite } & \text { sebè } & \text { na } & \text { zemi } \\ \text { father ACC.SG not } & \text { call 2.PL.IMP } & \text { yourself DAT } & \text { on } & \text { earth } \\ \text { 'do not call for yourself a father on the earth' } 1230900 & \end{array}$

Judging by the semantic variety of $s e$ forms, we might reasonably expect that some case variation in their complements could be expected and then, even though our reflexive pronoun could not show number or gender marking, the case marking could be visible as the 'full' pronominal form inflects for case regularly. Given the fact that such a situation can be expected, but it does not appear, it seems that the system does not treat $s e$ as a pronoun at all. 
Another argument is connected with the appearance of a sequence of $s e$ elements. If $s e$ was a regular pronominal element, we should expect it not to appear in the form of an overt marker in the contexts where the syntactic structure complements two consecutive verbs in the same way: For instance, in Polish we form the complex structure consisting of two clauses with identical pronominal objects in two ways, i.e. both objects may be overtly realized (slightly stylistically 'heavy' variant $20 \mathrm{a}$ ), or one of the pronouns ( $20 \mathrm{~b}$ ) can be covert:

(20) a. Szkodzę sobie $e_{\mathrm{i}}$, szczędzac sobie ' 'I hurt myself, grudging myself (everything)'

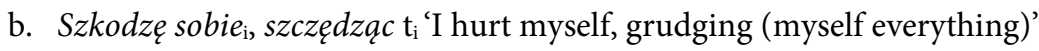

On the other hand, in the cases where we are dealing with lexical items having in their buildup the reflexive element, such a deletion of a pronominal argument cannot be performed:

(21) a. Ubierając się, nudzę się 'Dressing up, I am bored'

b. ${ }^{*}$ Ubierając się, nudzę

In OCS our reflexively marked verbs do not seem to allow the deletion of the clitic element, and double sę in complex sentences with two middle verbs is the norm:

(22) a. 1231200 iznesetǔ sę sǔměritǔ sę 'He (who) rises, will fall'

b. 1231210 i sǔměrějęi sę v iznesetǔ sę 'He (who) falls, will rise'

c. 1202220 az ǔkrǔštajo sę krǔstiti sę 'And, how I baptize, can you baptize?'

d. 1202300-10 krǐštajo sę krǔstita sę 'How I baptize, you will baptize.'

Altogether, the elements which are building parts of lexical items do not delete without consequences, while syntactic units can be eradicated, or moved around more easily. The above data shows that the reflexive verbs are rather lexical units in some significant sense, and not complexes of a verb and a pronoun.

Madariaga (2010) also claims that the psychological verbs have the reflexive passive structure, which means that the internal arguments land up as the subjects, while the Accusative case is taken up by the pronominal elements. That is why the remaining argument has to be realized as Genitive. Her arguments for the passive structure of her predicates consist in the possibility to add an agent like argument to the passive like structures.

However, the otǔ phrases, which express the causes of the change of state of the internal argument, typically do not have the agentive meaning. More often than not, do they copy the Ablative/Genitive function of PIE, which may be expressed as from. So it seems that the use of the Genitive case marked argument and the otǔ phrase (which incidentally attributes also the genitive case) are just competing ways of expressing the same function and convincing arguments to attribute the (originally) external argument (Agentive) function to this phrase are missing. Below we supply usual uses of the otǔ phrases in OCS, when they accompany reflexive verbs:

\footnotetext{
15 Actually, this sentence is grammatical with the meaning: 'While dressing up, I am boring somebody'. Consequently, the non-overt position is treated in causatives as argumental.
} 
(23) Non-Agentive otǔ phrases

1080310 ištisti sę otǔ prokazǔi ‘Clean yourself from the pestilence’

1111920 i opravìdi sę prèmodrostǐ otǔ čędǔ svoihŭ 'And wisdom justifies itself with its deeds'

1160600 bljudéte sę otǔ kvasa 'Be cautious of the acid'

1161110 hranite že sę otǔ kvasa 'Be cautious of the acid'

Occasionally, the agentive interpretation is also possible, but it is very rare: ${ }^{16}$

(24) 1230700 naricati sę otǔ člvkǔ ravivi ‘Be called rabbis by men’

Only the last case has the agentive meaning, while its agentive character probably results from the choice of the human argument, and not from the agentivity associated with its original function as the External Argument.

Another argument by Madariaga (2010) is connected with the lack of passive participles from the relevant verbs, but if they are mono-argumental, as we claim, this would also fall out. Incidentally, the verbs can appear in impersonal structures implying the passive semantics, which is to be expected if they are mono-argumental, but not if they are already passive: constructions with the verb in the third person singular and with the complement in the Dative case (e.g. vamú - you. DAT below) serve as the passive voice equivalents. Psychological verbs can appear in this structure, which would be hardly viable, were they already passive.

1212800 sę minnitǔ vamǔ (literally: '(It) thinks to you')

Also the co-ordination of 'mental separation' verbs with non-passive structures is perfectly grammatical, as the example below shows, whereas the co-ordination of active and passive clauses in e.g. Present-day Polish sounds odd. Of OCS a similar phenomenon can be expected:

\section{(26) 1170700 vǔstaněte i ne boite sę 'Get up and do not be afraid'}

Consequently, we feel that the assumption that 'mental separation' verbs are passive structures is not well documented for OCS and we discard this solution as an option which could shed some light on the overall picture of reflexive structures in OCS. Likewise, we do not find arguments for treating se as an argument in a clause spelled out by a defective pronominal element.

\section{Conclusion}

The solution where se realizes the middle voice head in a number of verbal structures with reasonably uniform semantics and not a pronominal argument seems to us to be a superior solution, supported by morphological make-up of the relevant forms, distributional phenomena and the properties of arguments that can appear with the relevant verbs. The possibility of the existence of something like the middle voice ${ }^{17}$ in Slavic languages has been postulated by Rokoszowa $(1978,1979)$. She quotes a number of arguments, diachronic,

\footnotetext{
16 Just a single example in our data.

17 In the original paper by Rokoszowa (1978) the term used is:strona zwrotna 'reflexive voice'.
} 
synchronic and typological, suggesting that the alleged middle voice in Slavic has been overlooked by researchers (cf. Kuryłowicz 1964). However, her conception of 'reflexive voice' differs from the one proposed here. Only the structures involving sentient participants are counted among her data, while we include here also classical anticausatives and statives, which typically do not qualify without sentient participants. Nevertheless, R Later development of the periphrastic passive voice with its characteristic marking adversely influenced the two voice system of OCS. Similarly, many reflexively marked anticausatives and statives turned into synthetic forms, as observable in e.g. nowadays Polish, so reflexive structures do not appear as frequently as they did. In contrast to so modified Modern Slavic languages, OCS shows signs of being active - middle, two voice system.

\section{References}

Alexiadou, A. 2010. On the morpho-syntax of (anti)causative verbs. In M. Rappaport Hovav, E. Doron, and I. Sichel (eds.), Lexical semantics, syntax, and event structure, 177-203. Oxford: Oxford University Press.

Alexiadou, A., and E. Anagnostopoulou. 2004. Voice morphology in the causative-inchoative alternation; evidence for a non-unified structural analysis of unaccusatives. In A. Alexiadou, E. Anagnostopoulou, and M. Everaert (eds.), The unaccusativity puzzle. Explorations of the syntax-lexicon interface, 114-136. Oxford: Oxford University Press.

Alexiadou, A., and E. Doron. 2012. The syntactic construction of two non-active voices: passive and middle. Journal of Linguistics 48 (1): 1-34.

Belletti, A., and L. Rizzi. 1988. Psych-verbs and $\theta$-theory. Natural Language and Linguistic Theory 6: $291-352$.

Brajerski, T. 1966. Język staro-cerkiewno-słowiański. Towarzystwo Naukowe Katolickiego Uniwersytetu Lubelskiego: Lublin.

Cennano, M. 1995. Patterns of 'active' syntax in Late Latin pleonastic reflexives. In J. Smith, and D. Lentley (eds.), Historical Linguistics 1995: Volume 1: General issues and non-Germanic languages.3653.Amsterdam: John Benjamins.

Chomsky, N. 1995. The Minimalist Program. Cambridge, MA: MIT Press.

Embick, D. 2004. On the structure of resultative participles in English. Linguistic Inquiry 35(3): 355-392.

Embick, D. 2009. Roots, states, and stative passives. Abstract for Root Workshop, University of Stuttgart.

Everaert, M., M. Marelj, and T. Siloni. 2012. The theta system: an introduction . In M. Everaert, M. Marelj, and T. Siloni (eds.), Argument structure at the interface,1-19. Oxford: Oxford University Press.

Gorković-Major, J. 2009. The role of syntactic transitivity in the development of Slavic syntactic structures. Wiener Slawistischer Almanach, Sonderband 74: 63-74.

Jasanoff, J. 2002-2003. Stative *-ē- revisited. Die Sprache 43(2): 127-170.

Junghanns, U., D. Ferhmann, and D. Lenertová. 2011. Decausatives in a minimal theory of reflexive marking. A paper presented on the 9th of December 2011 at FDSL conference in Göttingen, Germany.

Kratzer, A. 1996. Severing the external argument from its verb. In J. Rooryck, and L. Zarig (eds.), Phrase structure and the lexicon, 109-137. Dordrecht: Kluwer.

Krause, T., and J. Slocum. 2013. Old Church Slavonic online. http://www.utexas.edu/cola/centers

Kulikov, L. 2011. Passive to anticausative through impersonalization. The case of Vedic and Indo-European. In A. Malchukov, and A. Siewierska (eds.), Impersonal constructions. A cross-linguistic perspective, 229-254. Amsterdam: John Benjamins.

Kulikov, L. 2013. Middle and reflexive. In S. Luraghi, and C. Parodi (eds.), The Bloomsbury companion to syntax, 261-278. Bloomsbury: London.

Landau, I. 2010. The locative syntax of experiencers. Cambridge, MA: MIT Press.

Lomashvili, L. 2011. Complex predicates. The syntax-morphology interface. Amsterdam: John Benjamins.

Lunt, H. 2001. Old Church Slavonic Grammar. Mouton de Gruyter: Berlin. New York. 
Madariaga, N. 2009.The triggering of structural case-marked objects in Old and Present-Day Russian. Die Welt der Slaven special issue 2009. https://www.academia.edu/1024645/

Madariaga, N. 2010. The development of Indo-European middle-passive verbs: a case study in Ancient Greek and Old Church Slavonic. Indogermanische Forschungen. Zeitschrift für Indogermanistik und allgemeine Sprachwissenschaft 115: 149-178.

Marantz, A. 1984. On the nature of grammatical relations. Cambridge, MA: MIT Press.

Medová, L. 2011. Anticausatives are derived unergatives. In M, Ziková and M. Dočekal (eds.), Slavic languages in formal grammar. Proceedings of FDSL 8.5, Brno 2010, 272-291. Frankfurt am Main: Peter Lang.

Pantcheva, M. 2010. Directional expressions cross-linguistically: Nanosyntax and lexicalization. Nordlyd 36: $7-$ 39.

Pylkkänen, L. 2008. Introducing arguments. Linguistic Inquiry Monograph 48. Cambridge, MA: MIT Press.

Ramchand, G. 2008. Verb meaning and the lexicon: A first phase syntax. New York: Cambridge University Press.

Rothmayer, A. 2009. The structure of stative verbs. Amsterdam: John Benjamins.

Rozwadowska, B. (to appear). Psychological verbs and psychological adjectives. In The Blackwell Companion to Syntax.

Savčenko, A. N. 1974. Sravnitel'naja grammatika indoevropejskix jazykov. URSS: Moskva.

Slovnik jazyka staroslověnského. 1958. Praha: Nakladatelství Československié Akademie Věd.

Vaillant, A. 2002 [1948] Manuel du vieux slave. Paris. [Russian translation 2002 Rukovodstvo po staroslovjanskomu jazyku]. Moskva: URSS.

\section{Corpora}

Codex Marianus in the Corpus Cyrillo-Methodianum Helsingiense. http://www.helsinki.fi/slaavilaiset/ccmh/ Corpus PROIEL. http://www.tekstlab.uio.no:3000/users/sign_in 